\title{
KANDUNGAN MIOGLOBIN IKAN TUNA (Thunnus albacares) DENGAN PEMAKAIAN KARBON MONOKSIDA DAN FILTER SMOKE SELAMA PENYIMPANAN BEKU
}

\section{Myoglobin Content of Tuna Loin (Thunnus albacores) Treated by Carbon Monoxide and Filtered Smoke During Stored}

Cindy R. M. Loppies*, Daniel A. N. Apituley, Raja B. D. Sormin dan Beni Setha Program Studi Teknologi Hasil Perikanan Fakultas Perikanan dan Ilmu Kelautan Universitas Pattimura

\section{ABSTRAK}

Kerusakan daging sebagian disebabkan oleh pembentukan metmioglobin yang menyebabkan daging menjadi kecoklatan. Penggunaan karbon monoksida dan filter smoke yang mengandung senyawa CO yang akan bereaksi dengan mioglobin menjadi karboksimioglobin yang merupakan bentuk stabil dari pigmen merah dalam daging ikan tuna. Tujuan penelitian ini adalah mengetahui perubahan kandungan mioglobin daging ikan tuna dengan penggunaan gas CO dan FS selama penyimpann beku . Metode yang digunakan adalah metode eksperimen yaitu ikan tuna (Thunnus albacores) loin yang disemprot dengan gas CO dan FS selanjutnya disimpan beku selama empat minggu. Pengamatan dilakukan pada minggu ke0, 1, 2, 3 dan 4. Parameter uji adalah: Kandungan mioglobin, warna dan profil protein. Kandungan Mioglobin ikan tuna dengan gas CO dan FS selama penyimpanan masing-masing 31,34 $\mathrm{mg} \%, 29,05$ $\mathrm{mg} \%$, 31,25 mg\% ,36,28 mg\%, 41,01 mg\%, FS, 18,42 mg\%, 20,82 mg\%, 24,32 mg\%, 34,72 mg\% dan $52,48 \mathrm{mg} \%$. Analisa warna menujukan nilai kecerahan $\mathrm{L}^{*}$, untuk Gas CO dan FS selama penyimpanan berturut-berturut 26,33; 43,67; 36; 24,33; 20,33; FS adalah 30;42; 37; 27, 25,67. Untuk warna berdasarkan nilai $\mathrm{a}^{*}$ dan $\mathrm{b}^{*}$ dihitung berdasarkan ${ }^{0}$ Hue maka ikan tuna yang menggunakan gas CO berturut-turut adalah 47,26; 55,41; 54,42; 46,52; 42,09, sedangakan FS adalah 50,57; 55,82; 55,61; 50,81 dan 40,47, kedua gas ini dapat digolongkan pada warna merah. Profil protein ikan Tuna loin yang di berikan gas CO dan FS diperoleh 2 pita dengan berat molekul 100,92 kD dan 52,05 kD. Kesimpulannya Kandungan Mioglobin ikan tuna yang diberi gas CO dan FS selama penyimpanan terjadi peningkatan dan dikategorikn kualitas baik.

Kata kunci: filter smoke, karbon monoksida, mioglobin, dan tuna loin 


\begin{abstract}
A part of fish flesh denaturation was caused by the formation of metmyoglobin, which resulted brownish color. Carbon monoxide (CO) and filtered smoke (FS) will react myoglobine to establish carboximyoglobine the stable form of red figment of tuna flesh. The purpose of this study was to determine the myoglobin changes of tuna flesh by treated CO and FS during frozen storage. The research method was an experimental where the tuna (Thunnus albacores) loin was sprayed by CO and FS, then kept at frozen storage during 4 weeks. Observations carried out at $0,1,2,3$ and 4 weeks. The surveillance parameters were: myoglobin content, color and protein profile of tuna loin. The result showed the myoglobin content of tuna loin during storage at $0,1,2,3$, and 4 week were $31.34 \mathrm{mg} \%$, $29.05 \mathrm{mg} \%, 31.25 \mathrm{mg} \%, 36.28 \mathrm{mg} \%$ and $41.01 \mathrm{mg} \%$ respectively, while FS were $18.42 \mathrm{mg} \%, 20.82 \mathrm{mg} \%$, $24.32 \mathrm{mg} \%, 34.72 \mathrm{mg} \%$ and $52.48 \mathrm{mg} \%$ respectively. According to the color analysis of tuna loin treated by $\mathrm{CO}$ and $\mathrm{FS}$, it indicated that the brightness value $\mathrm{L}^{*}$ of the tuna loin treated by $\mathrm{CO}$ during storage at 0 , $1,2,3$, and 4 week were $26.33 ; 43.67 ; 36 ; 24.33$; and 20.33 resvectively and treated by FS there were 30 ; $42 ; 37 ; 27,25$, and 67 resvectively. The red color based on $a^{*}$ and $b^{*}$ values calculated by ${ }^{\circ}$ Hue, of the tuna loin treated by CO during storage at $0,1,2,3$, and 4 week were 47.26; 55.41; 54.42; 46.52; and 42.09 respectively and the tuna loin treated by FS were $50.57 ; 55.82 ; 55.61 ; 50,81$ and 40,47 respectively. It concluded that both tuna loin treated by $\mathrm{CO}$ and FS classified as red color. Profile of tuna loin protein treated by CO and FS obtained 2 bands indicated by molecular weights of $100.92 \mathrm{kD}$ and $52.05 \mathrm{kD}$. The myoglobin content of tuna treaded by CO and FS during storage increased so it categorized as a good quality.
\end{abstract}

Key words: carbon monoxide, filter smoke, myoglobin and tuna

\section{PENDAHULUAN}

Ikan tuna loin merupakan salah satu komoditi eksport yang merupakan produk yang sangat cepat menurun kualitasnya bila tidak ditangani denga baik. Salah satu faktor penentu agar tuna loin yang diekspor diterima oleh konsumen yaitu warna. Warna daging pada makanan laut memiliki pengaruh yang kuat pada penerimaan konsumen.Warna merah cerah merupakan faktor penting penentu kualitas pada makanan laut, terutama ikan tuna. Setelah dipotong dan selama penyimpanan beku, ikan tuna mengalami perubahan warna yang cepat menjadi warna coklat [1].

Penggunaan karbon monoksida (CO) maupun filtersmoke (FS) telah diterapkan pada makanan laut dalam upaya untuk mempertahankan warna yang diinginkan selama penyimpanan dan transportasi [2]. Penggunaan CO dan FS pada penelitian yang dilakukan [3] dan [4] untuk melihat stabilitas warna dan stabilitas bakteri pada ikan tuna (Thunnus albacares).
Menurut SNI 01-4104-2006, bahwa semua jenis tuna dapat dibuat menjadi produk tuna loin namun pada umumnya bahan baku tuna loin adalah yellowfin, bluefin, bigeye dan longfin, dan pada penilitian ini menggunakan yellowfin.

Oksidasi adalah reaksi antara suatu senyawa kimia dengan oksigen. Salah satu kemunduran mutu ikan tuna yang disebabkan oleh proses oksidasi yaitu terjadinya penambahan kation pada $\mathrm{Fe} 2+$ (ferrous) dalam mioglobin menjadi bentuk Fe3+ (ferric) yang dapat mengakibatkan perubahan warna daging ikan tuna dari merah segar menjadi coklat. [5]. Penyuntikan karbon monoksida pada daging ikan tuna dapat mempertahankan warna merah daging ikan tuna selama penyimpanan dan pengangkutan. Senyawa CO dapat bereaksi dengan myoglobin menjadi karboksimioglobin yang merupakan bentuk stabil dari pigmen merah dalam daging ikan tuna. Karboksimioglobin dapat mencegah terjadinya proses oksidasi dibanding oksimioglobin karena senyawa 
karbonmonoksida memiliki daya ikat yang lebih kuat terhadap mioglobin dibanding oksigen [6].

Penggunaan $\mathrm{CO}$ pada penanganan tuna loin pada saat ini tidak menjamin keeamanan pangan, dimana negara pengeksport tuna loin seperti Jepang menolak penggunaan CO. [5]. CO diganti dengan Filter Smoke (FS) hal ini berkaitan juga dengan residu yang terdapat pada jaringan otot [2]

FS adalah produk asap hambar yang diproduksi dengan pembakaran kayu dengan suhu $8500^{\circ} \mathrm{F}$ atau $454^{\circ} \mathrm{C}$ selanjutnya proses filtrasi dan pemurnian untuk menghilangkan partikulat yang ditemukan pada asap konvensional. Komponen utamanya dalam fiter smoke adalah nitrogen $\left(\mathrm{N}_{2}\right)$, oksigen $\left(\mathrm{O}_{2}\right)$, CO, karbon dioksida $\left(\mathrm{CO}_{2}\right)$ metana (CH4), fenol aromatik dan hidrokarbon [7] Hahn, 1999). Menurut [3]; [4], FS dapat mengurangi jumlah bakteri, meningkatkan stabilitas oksidatif dan stabilitas warna merah daging ikan tuna selama penyimpanana. Selanjutnya penggunaan FS dapat mengurangi oksidai lemak pada asam lemak dan pada gilirannya, akan mengakibatkan tertunda terjadinya penyimpangan rasa dan bau pada daging ikan [8]. Penelitian ini bertujuan mengetahui perubahan kandungan mioglobin daging ikan tuna dengan penggunaan gas $\mathrm{CO}$ dan FS selama penyimpann beku.

\section{METODE PENELITIAN}

\subsection{Waktu dan Tempat}

Penelitian ini dilakukan pada bulan November 2019 di PT Maluku Prima Makmur Ambon dan Analisa sampel dilakukan di Laboratorium MIPA Unpatti untuk analisa myoglobin Ambon dan Laboratorium Kimia dan Terpadu Universitas Diponegoro Semarang untuk analisa warna.

\subsection{Bahan dan Alat}

Bahan yang digunakan yaitu ikan tuna loin (Thunnus albacores) dari PT. Maluku Prima Makmur Ambon. Bahan kimia untuk analisa diantaranya pottasium buffer, $\mathrm{NaN}_{3}$, KCN, buffer phospat pH 6,8, Tris-HCL pH 6,8, MTris -HCL pH 8,8, larutan akrilamid dan APS (TEMED), merkaptoetanol (sigma), biophenol (sigma), bromphenol blue (sigma), Marker (Thermo Scientific). Alat yang digunakan adalah sentrifuse merk Hetttich Sentrifugen Universal 320R, kertas saring whatman berukuran $0,2 \mu \mathrm{m}$, spktrofotometer UV-VIS 2500, SDS Sodium Dodecyl Sulphate Polycrylamide Gel Electrophoresis (SDSPAGEeido-SGTN) dan Color reader (Minolta CR-10).

\subsection{Prosedur Penelitian}

Preparasi sampel dilakukan dengan cara ikan tuna loin yang didapat dari PT Maluku Prima Makmur Ambon, kemudian dilakukan penyemprotan dengan Gas CO, didapat dari PT Maluku Prima Makmur Ambon dan filter smoke (Carbon monoxide $30 \%$ to $40 \%$ in nitrogen) yang didapat dari PT Harta Samudra Ambon. Setelah Penyemprotan, sampel disimpan Pada suhu Pendinginan $4^{\circ} \mathrm{C}$ selama 2 hari, selanjutnya gas $\mathrm{CO}\left(\mathrm{A}_{1}\right)$ dan FS $\left(\mathrm{A}_{2}\right)$ dikeluarkan. Sampel di masukkan dalam plastik dan di vacum kemudian disimpan selama empat minggu dalam suhu pembekuan $-25{ }^{\circ} \mathrm{C}$. Pengamatan dilakukan pada minggu ke-0 $\left(\mathrm{B}_{0}\right)$, ke-1 $\left(\mathrm{B}_{1}\right)$, ke-2 $\left(\mathrm{B}_{2}\right)$, ke-3 $\left(\mathrm{B}_{3}\right)$ dan ke-4 $\left(\mathrm{B}_{4}\right)$. Parameter uji meliputi: kandungan mioglobin, warna dan profil protein.

\subsection{Analisis Mioglobin}

Sampel diblender hingga homogen, kemudian ditimbang sebanyak $1 \mathrm{~g}$ masukkan kedalam tabung sentrifuse $50 \mathrm{ml}$ dan ditambahkan $7 \mathrm{~mL}$ Aquabidest dingin, selanjutnya disentrifuse pada kecepatan 3000 G selama 15 menit. Sampel disaring dengan menggunakan kertas saring 0,2 $\mu \mathrm{m}$. Sampel dipipet $1 \mathrm{ml}$, kemudian ditambahkan $0,5 \mathrm{ml}$ pottasium buffer (25 $\mu \mathrm{m} \mathrm{pH}$ 7) divortex, ditambahkan $25 \mu \mathrm{l}$ larutan $\mathrm{NaNO}_{3} \quad 5 \%$, divortex dan selanjutnya tambahkan $25 \mu \mathrm{l}$ KCN 1\%, divortex dan didiamkan selama 1 menit. Larutan yang diperoleh diukur serapannya dengan spektrofotometer UV-VIS 2500 pada panjang gelombang $540 \mathrm{~nm}$ dengan buffer phospat $40 \mathrm{mM}$ pH 6,8 sebagai blanko [9]. Perhitungan konsentrasi mioglobin diukur berdasarkan koefisien 
molekul extinction (11300) dan berat molekul (16000) dengan rumus:

Konsentrasi $(\mathrm{mg} / 100 \mathrm{~g})=$ absorban $\mathrm{x} 2 \mathrm{x}$ $16000 / 11300 \times 100$

\subsection{Pengukuran Warna}

Pengukuran Warna menggunakan alat Color reader (Minolta CR-10). Sampel daging ikan dimasukkan dalam plastik transparan. Alat color reader dihidupkan, kemudian ditempelkan pada kantong plastik yang berisi sampel dan ditentukan target pembacaan $\mathrm{L}^{*}$, $a^{*}, b^{*}$, color reader dan diukur warnanya. Penetuan warna menggunakan rumus derajat Hue .

$$
{ }^{\circ} \text { Hue }=\tan ^{-1}(b / a)
$$

Tabel 1. Pengelompokan Warna Berdasarkan Nilai ${ }^{\circ} \mathrm{Hue}$.

Table 1. Color Grouping Based on ${ }^{\circ}$ Hue Values

\begin{tabular}{cc}
\hline Kisaran/Range ${ }^{\mathbf{H}}$ Hue & Kelompok Warna/Color Group \\
\hline $342-18$ & Merah keunguan/Purplis red \\
$18-54$ & Merah/Red \\
$54-90$ & Kuning Kemerahan/Reddish yellow \\
$90-126$ & Kuning/Yellow \\
$126-162$ & Kuning Kehijauan/Greenish Yellow \\
$162-198$ & Hijau/Green \\
$198-234$ & Biru Kehijauan/Greenish Blue \\
$234-230$ & Biru/Blue \\
$270-306$ & Biru Keunguan/Purplis blue \\
$306-342$ & Ungu/Purple \\
\hline Sumber: $[10]$ &
\end{tabular}

\subsection{Pemisahan Protein dengan Metode SDS-PAGE (Sodium Dodecyl Sulphate Polycrylamide Gel Electrophoresis)}

Teknik pemisahan protein dengan elektroforesis dilakukan dalam tiga tahap, yaitu ekstraksi protein dari sampel, pembuatan gel dengan menggunakan sodium dodecyl sulfat-polyacrilamide gel electrophoresis (SDS-PAGE) dan pendeteksian pita-pita atau fraksi-fraksi protein yang terbentuk. [11].

\section{Pembuatan Sampel Buffer}

Preparasi sampel menggunakan sampel buffer yang terdiri dari $4 \mathrm{ml} \mathrm{dH}_{2} 0 ; 1 \mathrm{~mL}$ larutan 0,5 M Tris-HCL pH 6,8; 0,8 ml gliserol; $1,6 \mathrm{~mL}$ larutan SDS $10 \% ; 0,4 \mathrm{ml}$ larutan $\beta$ mercaptoethanol; $\quad 0,2 \mathrm{ml}$ larutan bromophenol blue $0,05 \%$. Supernatannya diambil $20 \mu \mathrm{l}$ lalu ditambah lemle sebanyak $20 \mu$ dengan 28 perbandingan 1:1.
Supernatan dicampur dengan lemle dipanaskan dengan suhu $100^{\circ} \mathrm{C}$ selama 5 menit tujuannya agar terjadi reaksi enzimatis. Tahap selanjutnya didinginkan, dimasukkan ke dalam sumur sebanyak $30 \mu \mathrm{l}$, kemudian dianalisis pola-pola atau pita-pita menggunakan SDS-PAGE (Sodium Dodecyl Sulphate Polycrylamide Gel Electrophoresis).

\section{Pembuatan Gel Pemisah}

Pembuatan gel pemisah (running gel) konsentrasi $12 \%$ (resolving gel/lapisan bawah) terdiri dari $3.200 \mu \mathrm{l} \quad \mathrm{dH} 20$ ditambahkan $2.500 \mu \mathrm{l}$ larutan 1,5 MTris-HCL pH 8,8; $100 \mu \mathrm{l}$ larutan SDS 10\%; $4.050 \mu \mathrm{l}$ larutan akrilamid 30\%; $50 \mu \mathrm{l}$ larutan APS 10\%; $16 \mu \mathrm{l}$ TEMED) dan 4\% stacking gel (lapisan atas) terdiri dari $3.050 \mu \mathrm{l} \quad \mathrm{H}_{2} \mathrm{O}$ ditambahkan $1.250 \mu$ larutan 0,5 M Tris-HCL pH 6,8; $50 \mu \mathrm{l}$ larutan SDS 10\%; $650 \mu \mathrm{l}$ larutan akrilamid 30\%; $25 \mu \mathrm{l}$ larutan APS $10 \%$; $6 \mu \mathrm{l}$ TEMED) (harus selalu dalam keadaan baru 
dilarutkan). Gel pengumpul (stacking gel) dicetak dengan bantuan "sisir" (comb) untuk memisahkan sumur-sumur sampel. Ketebalan gel yang dibuat adalah $4 \mathrm{~mm}$. Gel yang diperoleh kemudian dipasang, dan setelah gel mengeras sisir diangkat.

\section{Elektroforesis}

Proses pemisahan protein menggunakan buffer pemisah (running buffer)yang terdiri dari Tris HCL $9 \mathrm{~g}$, glycine 43,2 g, SDS $10 \% 3 \mathrm{~g}$ dan H2O sebanyak 600 mL. Buffer elektroforesis dimasukkan dan alat elektroforesis dirangkai. Sampel lalu dimasukkan ke dalam sumur dengan menggunakan mikro pipet sebanyak 10-20 $\mu \mathrm{L}$, tergantung tebal tipisnya pita protein yang diinginkan. Perangkat elektroforesis dijalankan pada suhu rendah dengan tegangan 100 volt dan arus $125 \mathrm{~mA}$ selama 11,5 jam hingga bromphenol blue mencapai 1 $\mathrm{cm}$ dari batas bawah gel. Setelah elektroforesis selesai, gel difiksasi dengan larutan Commassie brilian blue R-250 (larutan $0,05 \%$ commassie blue sebanyak 0,50 gram yang dilarutkan dalam $45 \%$ methanol sebanyak $225 \mathrm{~mL}$ dan $10 \%$ acetic acid sebanyak $50 \mathrm{~mL}$ dalam 45\% $\mathrm{dH} 20$ ), kemudian gel dipucatkan dengan larutan destain yang terdiri dari campuran 50\% dH2O $250 \mathrm{~mL} ; 10 \%$ acetic acid $50 \mathrm{~mL} ; 40 \%$ methanol $200 \mathrm{~mL}$, gel direndam dengan pewarnaan biru konasi (sambil digoyanggoyang) selama 24 jam. Gel dipucatkan dengan larutan peluntur dan digoyanggoyangkan sampai terlihat pita-pita protein [11]. Pita-pita protein yang muncul dan hasil SDS-PAGE dihitung retardation faktor (Rf) dengan menggunakan rumus:

$$
\mathrm{Rf}=\frac{\text { Jarak pergerakan pita protein dari tempat awal }}{\text { Jarak pergerakan warna pelacak dari tempat awal }}
$$

Berdasarkan nilai Rf berat molekul dihitung dengan persamaan regrasi logaritma dengan rumus : $\mathrm{Y}=(\mathrm{a} \times \mathrm{L}(\mathrm{X}))+\mathrm{b}$ mengacu pada penelitian [19]. Persamaan ini diperoleh dari grafik antar Log BM sebagai ordinat dan Rf sebagai absis. Berat molekul pita-pita protein dapat dihitung berdasarkan kurva kalibrasi:

Keterangan :

$\mathrm{Y}=$ berat molekul

$\mathrm{X}=$ nilai Rf sampel

$\mathrm{a}=$ nilai koefisien

$\mathrm{b}=$ nilai konstanta

\subsection{Analisis Data}

Analisis data hasil penelitian yang diperoleh dianalisis secara statistik deskriptif dan ditampilkan berupa tabel dan histogram. Faktor yang dikaji yaitu gas CO $\left(\mathrm{A}_{1}\right)$; FS $\left(\mathrm{A}_{2}\right)$, dan lama penyimpanan beku $0,1,2,3,4$, minggu $\left(B_{0}, B_{1}, B_{2}, B_{3}, B_{4}\right)$.

\section{HASIL DAN PEMBAHASAN}

\subsection{Mioglobin}

Persepsi terhadap warna daging mentah khususnya pada daging ikan tuna loin mempengaruhi keputusan konsumen untuk membeli. Daging dengan warna menyimpang dianggap sebagai daging berkualitas rendah. Kerusakan daging sebagian disebabkan oleh pembentukan met-Mb, menghasilkan daging menjadi kecoklatan. Rasio turunan Mb, yaitu, deoxyMb, oxyMb, dan metMb ditentukan berdasarkan penyerapan spektrofotometri dari ekstrak daging.

Hasil analisa memperlihatkan kandunan mioglobin tuna loin yang diberi gas C0 dari minggu ke-1, 2, 3, dan 4 maingmasing 31,34 mg\%, 29,05 mg\%, 31,25 mg\% dan 41,01 mg\%, sedangkan untuk gas FS berurut-turut, 18,42 mg\%, 20,82 mg\%, 24,32 mg\%, 34,72 mg\% dan 52,48mg\%. (Gambar 1). Untuk CO dan FS sampai akhir penyimpanan minggu ke-4 terlihat kandungan mioglobin masing-masing 41, 01 $\mathrm{mg} \%$, dan 52,48 mg \%. Penelitian [12] kandungan $\mathrm{Mb}$ pada yellowin tuna untuk kriteria sangat baik, baik, dapat diterima dan tidak dapat diterima masing-masing $157 \mathrm{mg}$ \%; 63,7 mg \% ; 50,6 mg \% dan $22.6 \mathrm{mg} \mathrm{\% ,}$ dengan demikian terlihat peningkatan kandungan mioglobin sehingga ikan tuna loin pada penelitian ini dapat dikategorikan baik untuk ikan tuna loin dengan Filter Smoke, sedangkan untuk tuna loin pemberian gas 
karbon dikategorikan dapat diterima. Warna merah pada daging walaupun dengan

konsentrasi CO yang rendah $<1 \%$.

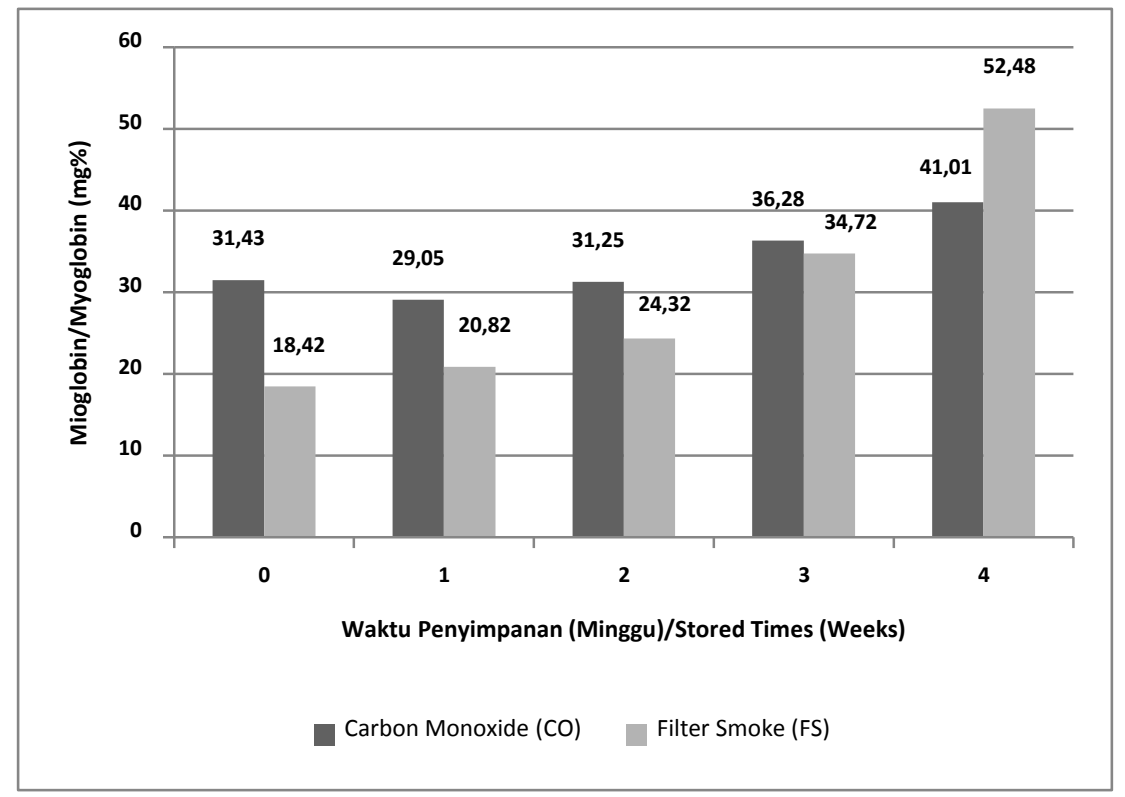

Gambar 1. Histogram Kandungan Mioglobin Tuna Loin dengan Perlakuan Jenis Gas CO dan FS selama penyimpanan.

Fig. 1. Histogram of Tuna Loin Myoglobin Content with Treatment The type of CO Gas and FS During Stored.

Peningkatan ini menggarah pada perbaikan warna merah pada daging ikan dengan pemberian gas yang mengandung $\mathrm{CO}$, FS dan limbah produksi asap cair dalam keadaan anaerobic. [13] menyatakan CO memiliki kemampuan tinggi dalam mempertahankan warna pada ikan. Peningkatan nilai mioglobin berhubungan dengan pembentukan Carboximioglobin. [14] menyatakan CO digunakan pada ikan seperti mahi-mahi (Coryhae hippurus) dan Mackerel (Scomberomous maculates) untuk mempertahankan dan memperbaiki warna daging merah dimana carboksimioglobin (COMb) tidak dapat stabil dalam keadaan aerobic, untuk itu perubahan mioglobin menjadi oxymioglobin (oxyMb) tidak dapat bertahan lama dalam keadaan aerobik dan selanjutnya akan berubah menjadi metmioglobin (metMb), untuk itu dalam menggunakan gas $\mathrm{CO}$ pada daging ikan diaplikasikan juga dengan menggunakan
Modified atmosphere packaging (MAP) dan penyimpanan dingin.

Penggunaan gas $\mathrm{CO}$ untuk menstabilkan $\mathrm{Mb}$ dalam bentuk $\mathrm{Fe}^{2}+$ seperti $\mathrm{CO}-\mathrm{Mb}, \mathrm{CO}$ mengikat sangat kuat $\mathrm{Mb}$ [15]. Hal ini tergambar oleh afinitas yang tinggi dan disosiasi yang sangat rendah. Sebagai contoh, afinitas $\mathrm{CO}$ ke $\mathrm{Mb}$ diperkirakan 100 kali lebih tinggi pada met-Mb [16]. CO terdisosiasi 1000 kali lebih lambat dari pada oksigen pada $\mathrm{Mb}$ [6].

\subsection{Warna}

Warna merah terang pada otot tuna merupakan faktor penting dalam menentukan nilai ekonomis [17], karena preferensi konsumen yang menganggap warna merah pada daging ikan sebagai indikator kesegaran [18]. Warna ini juga digunakan untuk menentukan perubahan fisik dari pangan. Salah satu metode mengukur warna dengan sistem notasi Huter 
menggunakan tiga dimensi warna $\mathrm{L}^{*}, \mathrm{a}^{*}, \mathrm{~b}^{*}$. $\mathrm{L}^{*}$ adalah menunjukan tingkat kecerahan dari warna dimana angka 0 menunjukkan warna hitam dan angka 100 warna putih. a* menunjukkan warna hijau dan merah, sedangkan $\mathrm{b}^{*}$ menunjukkan warna biru dan kuning. Nilai $\mathrm{L}^{*}$ dari Tuna Loin dengan perlakuan Gas CO dan FS Selama Penyimpanan dapat dilihat pada Tabel 1.

Tabel 2. Nilai L* dari Tuna Loin dengan perlakuan Gas CO dan FS Selama Penyimpanan.

Table 2. The $\mathrm{L}^{*}$ value of Tuna Loin's fish treated CO Gas and FS Gas During Stored.

\begin{tabular}{lc}
\hline Perlakuan/Treatment & $\mathbf{L}^{*}$ \\
\hline $\mathrm{A}_{1} \mathrm{~B}_{0}$ & $26.33 \pm 1,15$ \\
$\mathrm{~A}_{1} \mathrm{~B}_{1}$ & $43,67 \pm 0,58$ \\
$\mathrm{~A}_{1} \mathrm{~B}_{2}$ & $36 \pm 0,00$ \\
$\mathrm{~A}_{1} \mathrm{~B}_{3}$ & $24,33 \pm 1,15$ \\
$\mathrm{~A}_{1} \mathrm{~B}_{4}$ & $20,33 \pm 0,58$ \\
$\mathrm{~A}_{2} \mathrm{~B}_{0}$ & $30 \pm 0,00$ \\
$\mathrm{~A}_{2} \mathrm{~B}_{1}$ & $42 \pm 2,00$ \\
$\mathrm{~A}_{2} \mathrm{~B}_{2}$ & $37 \pm 1,15$ \\
$\mathrm{~A}_{2} \mathrm{~B}_{3}$ & $27 \pm 0,58$ \\
$\mathrm{~A}_{2} \mathrm{~B}_{4}$ & $25,67 \pm 1,00$ \\
\hline$n=2$ &
\end{tabular}

Hasil penelitian menunjukkan ikan tuna loin yang diberi gas CO dan ,FS, pada penyimpanan minggu ke-0 hingga minggu ke -4 memilki nilai $L^{*}$ (kecerahan) pada Tabel 2. Nilai tertinggi pada tuna loin dengan penggunaan gas $\mathrm{CO}$ penyimpanan minggu ke1 yaitu 43.67 dan nilai terendah pada tuna loin dengan penggunaan gas $\mathrm{CO}$ dan penyimpanan minggu ke- 4 yakni 20,33. Jika dihubungkan dengan nilai $a^{*}, b^{*}$ dan derajat ${ }^{0}$ Hue memperlihatkan kecerahan dan berwaran kuning kemerahan hingga merah.
Warna adalah parameter sensorik utama yang menentukan penerimaan konsumen terhadap daging. Perubahan warna yang disebabkan oleh oksidasi dari miogobin $(\mathrm{Mb})$ menjadi met mioglobin (met$\mathrm{Mb}$ ). Daging yang berwarna merah dianggap masih segar dan yang memberikan warna merah pada ikan tuna loin adalah kandungan mioglobinnya [16]. Warna tuna loin dengan gas CO dan FS selama penyimpanan dapat dilihat pada Tabel 3 .

Tabel 3. Warna Tuna Loin Dengan Gas CO dan FS Selama Penyimpanan

Table 3. Meat Color of Tuna Loin with Gas CO and FS During Stored

\begin{tabular}{lcc}
\hline Perlakuan/Treatment & oHue & $\begin{array}{c}\text { Keterangan Warna/ } \\
\text { Color Description }\end{array}$ \\
\hline $\mathrm{A}_{1} \mathrm{~B}_{0}$ & $47,26 \pm 0,62$ & Merah/Red \\
$\mathrm{A}_{1} \mathrm{~B}_{1}$ & $55,41 \pm 0,96$ & Kuning kemerahan/Reddish \\
$\mathrm{A}_{1} \mathrm{~B}_{2}$ & $54,42 \pm 0,51$ & Kuning kemerahan/Reddish \\
$\mathrm{A}_{1} \mathrm{~B}_{3}$ & $46,52 \pm 0,89$ & Merah/Red \\
$\mathrm{A}_{1} \mathrm{~B}_{4}$ & $42,09 \pm 0,66$ & Merah/Red \\
$\mathrm{A}_{2} \mathrm{~B}_{0}$ & $50,57 \pm 1,33$ & Merah/Red \\
$\mathrm{A}_{2} \mathrm{~B}_{1}$ & $55,82 \pm 0,56$ & Kuning kemerahan/Reddish \\
$\mathrm{A}_{2} \mathrm{~B}_{2}$ & $55,61 \pm 0,94$ & Kuning kemerahan/Reddish \\
$\mathrm{A}_{2} \mathrm{~B}_{3}$ & $50,81 \pm 1,12$ & Merah/Red \\
$\mathrm{A}_{2} \mathrm{~B}_{4}$ & $40,27 \pm 2,21$ & Merah/Red \\
\hline$n=2$ & &
\end{tabular}




\begin{abstract}
Mioglobin merupakan pigmen utama daging dan konsentrasinya akan mempengaruhi intensitas warna merah daging. Perbedaan kadar miglobin menyebabkan perbedaan intensitas warna daging [15].
\end{abstract}

\section{Profil Protein}

Elektroforesis adalah suatu proses migrasi molekul bermuatan dalam larutan atau medium melalui pengaruh medan listrik yang juga sering digunakan untuk menentukan komposisi protein dari suatu produk pangan [19]. Metode yang paling umum untuk memisahkan protein adalah dengan cara elektroforesis menggunakan polyacrylamide gel sebagai medium penyangga dan sodium dodecyl sulfate (SDS) untuk mendenaturasi protein. Ketika protein dan makromolekul lainnya ditreatment dengan SDS, maka akan terdenaturasi dan bermuatan negatif. Molekul yang lebih besar akan tertahan dan akibatnya bergerak lebih lambat sehingga molekul terdenaturasi, diameternya tergantung dari berat molekulnya, dan SDSPAGE akan memisahkan molekul berdasarkan berat molekul. Teknik elektroforesis telah banyak digunakan dalam analisis protein untuk menentukan tingkat kemurnian sampel, berat molekul, maupun titik isoelektrik [19] .

Profil SDS Page protein ikan Tuna loin yang di berikan gas CO, dan selama penyimpanan terdiri dari 2 (dua) pita protein., ke-2 pita protein tersebut mempunyai bobot molekul masing-masing 100,92; dan 51,05 (Tabel 4). Perhitungan bobot molekul relatif tersebut dilakukan dengan menggunakan kurva standart bobot molekul relatif dengan persamaan regresi $\mathrm{Y}=$ $-0,653 X+2,06$ dan $R^{2}=0,978$, yang disajikan pada Tabel.3, sebagai molekul pembanding (marker protein) yang digunakan dengan ukuran 100 KDa - 28 KDa. Dari dan Tabel 4, dapat diketahui bobot molekul protein ikan tuna loin yang di berikan gas CO dan FS selama penyimpanan berkisar antara 100 $48 \mathrm{kDa}$.

Tabel 4. Berat Molekul Protein ikan Tuna Loin dengan Gas CO dan FS Selama Penyimpanan Minggu ke- 0 dan 4.

Table 4. Molecular Weight of Tuna Loin Fish Protein with CO Gas And FS During Stored 0 and 4 Weeks

\begin{tabular}{ccccccc}
\hline $\begin{array}{c}\text { BM Marker } \\
\text { Protein/ } \\
\text { MW Protein } \\
\text { Markers (kDa) }\end{array}$ & $\begin{array}{c}\text { Log BM } \\
\text { Marker } \\
\text { Protein/MW } \\
\text { Log Markers } \\
\text { Protein }\end{array}$ & $\begin{array}{c}\text { Rf Marker } \\
\text { Protein/Rf } \\
\text { Protein } \\
\text { Markers }\end{array}$ & $\begin{array}{c}\text { Rf } \\
\text { Sampel/ } \\
\text { Rf Sample }\end{array}$ & $\begin{array}{c}\text { Log BM } \\
\text { Sampel/MW } \\
\text { Log Sample }\end{array}$ & $\begin{array}{c}\text { BM } \\
\text { Sampel/ } \\
\text { MW } \\
\text { Sample }\end{array}$ & $\begin{array}{c}\text { Keterangan/ } \\
\text { Description }\end{array}$ \\
\hline 100 & 2 & 0,109 & 0,091 & 2,004 & 100,92 & $1,2,3,4$. \\
75 & 1,875 & 0,309 & & & & \\
63 & 1,799 & 0,436 & & & & \\
48 & 1,681 & 1,799 & 0,545 & 1,708 & 51,05 & $1,2,3,4$. \\
35 & 1,544 & 1,681 & & & & \\
28 & 1 & 1,447 & & & & \\
\hline
\end{tabular}

Keterangan : 1= Ikan Tuna loin dengan gas CO minggu 0/Tuna Loin with gas CO, 0 Week 2= Ikan Tuna loin dengan gas FS minggu minggu 1/Tuna Loin with gas FS, 0 Week $3=$ Ikan Tuna loin dengan gas CO minggu 4/Tuna Loin with gas CO, 4 Week 4= Ikan Tuna loin dengan gas FS minggu minggu 4/Tuna Loin with gas FS, 4 Week 


\section{KESIMPULAN}

Hasil penelitian ini dapat disimpulkan bahwa kandungan mioglobin ikan tuna yang diberi gas CO dan FS selama penyimpanan beku mengalami peningkatan, hingga minggu ke-4, yakni untuk ikan tuna dengan pemberian gas $\mathrm{CO}$ dan FS dengan nilai masing-masing 41,01 mg\%, dan 52,48 mg \%, dengan demikian ikan tuna loin pada dapat dikategorikan baik untuk penggunaan gas FS, sedangkan untuk gas CO dikategorikan dapat diterima. Hal ini juga didukung dengan Warna berdasarkan penetuan derajat hue yaitu warna Merah, dan terdapat 2 (dua) pita protein yang terbentuk dengan berat molekul $100,92 \mathrm{kD}$ dan 52,05 kD.

\section{DAFTAR PUSTAKA}

[1] Anderson CR., Wu WH. 2005. Analysis of carbon monoxide in commerically treated tuna (Thunnus spp.) and mahi-mahi (Coryphaena hippurus) by gas chromatography/mass pectrometry. J Agric Food Chem 53:7019-7023.

[2] Pivarnik, Lori F., Faustman, Cameron, Rossi, Santiago, Suman, Surendranath P., Palmer, Catherine, Richard, Nicole L., Ellis, Christopher P., DiLiberti, and Michael. Quality assessment of filtered smoked yellowfin tuna (thunnus albacares) steaks. 2011. Publications, Agencies and Staff of the U.S. Department of Commerce. Paper 307.

[3] Ludlow N., Kristinsson HG., Balaban MO., Otwell WS., Welt B. 2004. Effect of different carbonmonoxide and filtered smoke treatments on the quality and safety of yellowfin tuna (Thunnus albacares) muscle. IFT annual meeting. Las Vegas, Nev. Abstract 49B-26. Chicago, Ill, Institute of Food Technologists.

[4] Kristinsson. HG., Mony. S., Demir N. Balaban. M. 0. and Otwell WS. 2008. The effect of carbon monoxide and filtered smoke on the properties of aquatic muscle and selected muscle com ponents. Proceedings of the TAFT 2003 Conference. Reykjavik. Iceland: pp. 27-29.

[5] Faustman C., Cassens RG., Schaefer DM., Buege DR., Williams SN., and Sheller KK. 1989. Improvement of pigment and lipid stability in holstein steer beef by dietary supplementation of vitamin E. Journal of Food Science, 54:858.

[6] Livingston DJ., and Brown WD. 1981. The chemistry of myoglobin and its reactions. Meat pigments, food quality indices. Food Technology, 38: 238-252.

[7] Hahn MJ. 1999. Use of tasteless smoke. Washington DC. Hawaii International Seafood, Inc.

[8] Faustman C. dan Cassens RG. 1990. The biochemical basic for discoloration in fresh meat. A review. J Muscle Foods 1(3): 217-243.

[9] Chen WL., Chow CJ. 2001. Studies on the phsycochemical properties of milkfish myoglobin. Journal of Food Biochemistry, 25:157-174.

[10] Wenno M.R., 2017 Potensi Peptida bioaktif bakasang ikan cakalang (Katsuwonus pelamis) sebagai inhibitor angiotensin converting enzyme (ACE) dan pengujiannya pada tikus (Rattus nogergitus) model hipertensi induksi deokxicorticosterone acetate (doca-salt). Disertasi, Program Pascasarjana Fakultas Perikanan dan Kelautan Universitas Brawijaya.

[11] Nurimala M., Usho H., Keneko G., Ochiai Y. 2013. Assessment of commercial quality evaluation of yellowfin tuna (Thunus albacores) meat based on myoglobin properties. Food Sci Tekchology Res. 19(2): 237-243.

[12] Nurimala M. 2013. Studies on the structural discoloration. (Disertasi)/ Tokyo: The Graduate School of Agriculture and life sciences, The University of Tokyo.

[13] Smulevich G., Droghetti E., Focardi C., Coletta M., Ciaccio C., Nocentini M. 2007. A rapid spectroscopic method to detect the fraudulent treatmen of tuna fish with carbon monoxide. Food chemestry 101: 1071-1077.

[14] Neerhling NE., Louwrens C.. Hoffman, Trevor J. Brits, Bernadette 0' Niell. 2015. Influence of carbon monoxide on the colour stability of detrosted yellowfin tuna (Thunus albacores) muscle stored under aerobic and aerobic condition. Journal of the science of food agricultur, 01: 1605-1612.

[15] Schubring R. 2007.Use of filtered smoke and carbon monoxide with fish. Journal of consumer protection and safety, 3: 31-44.

[16] Narn,KC. and Ahn DC. 2003. Effects of irradiation on meat colour. Food sience biotecnology 12: 198- 205. 
[17] Ochiai Y., Chow Ci-]., Watabe S. and Hashimoto K. 1988. Evaluation of tuna meat discoloration by Hunter colour difference scala. Nippon Suisan Gakkaishi, 54: 649-653.

[18] Ishiwata H., Takeda Y. Kawasaki Y., Yoshida R., Sugita T., Sakamoto S. and Yamada T. 1996. Concentration of carbon monoxide in commercial fish flesh and in fish flesh exposed to carbon monoxide gas for color fixing. J Food Hygienic Soc Japan, 37:83-90.

[19] Murniati WSI., Trilaksani W., Nurimala M. 2014.

Perubahan Mioglobin Selama Penyimpanan Suhu Chiling. Jurnal Pengolahan Hasil Perikanan Indonesia, 